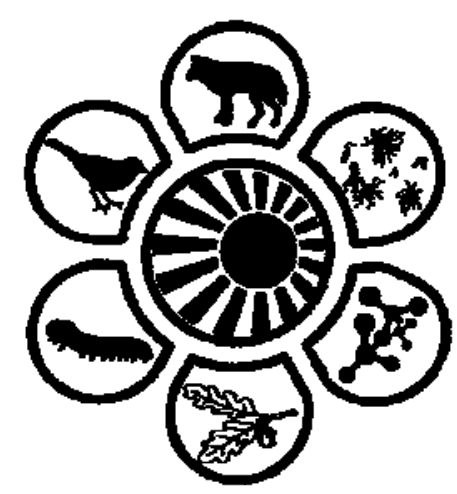

Вісник Дніпропетровського університету. Біологія, екологія. Vìsnik Dnìpropetrovs'kogo unìversitetu. Serîa Bìologîâ, ekologìâ

Visnyk of Dnipropetrovsk University. Biology, ecology. 2013. 21(2)

ISSN 2310-0842

www.ecology.dp.ua

УДК 577.1:638.138(045)

\title{
Белково-липидный состав пылыцы березы бородавчатой (Betula verrucosa) и ее антиоксидантная активность в зависимости от места произрастания
}

\author{
Т.В. Шевцова ${ }^{1}$, Е.Г. Гаркавая ${ }^{1}$, Я. Бриндза ${ }^{2}$, Т.С. Брюзгина ${ }^{3}$, В.А. Гроза ${ }^{1}$ \\ ${ }^{1}$ Начиональный авиачионный университет, Киев, Украина \\ ${ }^{2}$ Словаџкий аграрный университет, Нитра, Словацкая Республика \\ ${ }^{3}$ Национальный медицинский университет имени А.А. Богомольцุа, Киев, Украина
}

Исследованы белковый и липидный состав и биологическая активность 10 образцов пыльцы Betula verrucosa Ehrh. из разных мест произрастания на территории Украины и Словакии. Определено содержание белков (17,9-25,6\%) и 8 жирных кислот (с числом углеродных атомов от 14 до 20) в составе липидов. Выявлено преобладание ненасыщенных жирных кислот (58,6\%) с доминированием пальмитиновой $(33,9 \%)$, олеиновой $(29,5 \%)$ и линолевой $(27,8 \%)$. Оценена общая антиоксидантная активность водных, этаноловых и метаноловых экстрактов пыльцы березы бородавчатой с использованием свободного стабильного радикала дифенилпикрилгидразила колориметрически в реакции in vitro. Установлены статистически достоверные различия между образцами как внутри украинских и словацких генотипов, так и между ними. Рассматриваются факторы влияния на вариации белковолипидного состава пыльцы и ее биологической активности.

Ключевые слова: пыльца; белок; жирнокислотный состав липидов; общая антиоксидантная активность; радикал ДФПГ

\section{Protein-lipid composition of silver birch (Betula verrucosa) pollen and its antioxidant activity depending on habitat}

\author{
T. Shevtsova ${ }^{1}$, E. Garkava ${ }^{1}$, J. Brindza ${ }^{2}$, T. Brjuzgina ${ }^{3}$, V. Groza ${ }^{1}$ \\ ${ }^{\text {I}}$ National Aviation University, Kiev, Ukraine \\ ${ }^{2}$ Slovak University of Agriculture, Nitra, Slovak Republic \\ ${ }^{3}$ Bogomolets National Medical University, Kiev, Ukraine
}

Pollen has various effects on the human body. In order to study and compare the biological activity of the mature pollen grains of Betula verrucosa Ehrh. we investigated the protein-lipid composition and total antioxidant activity (TAA) of 10 samples from different habitats in the territory of Ukraine and the Slovak Republic. The collection sites are near highways and apartment blocks, as well as a nature reserve, forest and botanical garden. The protein content was determined by the Kjeldahl method. A chromatographic analysis of fatty acids from lipids was performed using a "Cvet 500" gas chromatograph, equipped with a flame-ionization detector in the isothermal mode. The bioactivity of aqueous, ethanol and methanol extracts of pollen grains was evaluated by the DPPH free radical scavenging method (2,2-diphenyl1-picrylhydrazyl) by means spectrophotometry in vitro. The protein content of the pollen of $B$. verrucosa ranged from $17.9 \%$ to $25.6 \%$, depending on the habitat. Unsaturated fatty acids were found in higher amounts than saturated fatty acids. The profile of fatty acids indicates a higher content of palmitic (33.9\%), oleic $(29.5 \%)$ and linoleic $(27.8 \%)$ acids and a low content of arachidonic $(0.4 \%)$ and pentadecanoic

\footnotetext{
${ }^{1}$ Национальный авиационный университет, пр. Космонавта Комарова, 1, 03680, Киев, Украина National Aviation University, Kosmonavta Komarova ave. 1, 03680, Kiev, Ukraine Tel.: +38097-801-02-50.E-mail: shevtsovat@ukr.net,immunolog@ukr.net

${ }^{2}$ Словаикий аграрный университет, Институт охраны биоразнообразия и биологической безопасности, Триеда А. Глинку 2, 949 76, Нитра, Словакия

Slovak University of Agriculture, Institute of Biodiversity Conservation and Biosafety, Trieda A. Hlinku 2, 949 76, Nitra, Slovakia Tel.: +42137-641-47-87. E-mail: Jan.Brindza@uniag.sk

${ }^{3}$ Национальный медицинский университет имени А.А. Богомольциа, пр. Победы, 34, Киев, Украина Bogomolets National Medical University, Pobeda avenue, 34, Kiev, Ukraine. Tel.: +38044-454-49-17
} 
$(0.8 \%)$ acids. We also established that silver birch pollen is characterized by high antioxidant activity. The measured value of TAA for aqueous pollen extracts was within $74.8-85.5 \%$. For the ethanol extracts it was quantified within $60.3-95.0 \%$ and for the methanol extracts 46.1-92.6\%. The Tukey test was used to determine the differences between the means at a level of $P<0.05$. A strong correlation coefficient (0.70) was defined between the protein content and the TAA of aqueous extracts. In general, the Ukrainian and Slovak samples of pollen differ in the fatty acid composition of lipids and aqueous and ethanol TAA extracts. Pollen of $B$. verrucosa should be used for diagnostic, therapeutic and prophylactic purposes as close as possible to the place of origin.

Keywords: pollen; protein; fatty acid composition of lipids; total antioxidant activity; DPPH radical

\section{Введение}

Ценность пыльцы состоит не только в обеспечении репродукции растений. Основываясь на современных знаниях, пыльца - источник энергии и питательных веществ. Определенное качественное и количественное содержание органических и неорганических соединений показывает, что пыльца представляет собой сложную и разнообразную биохимическую систему. Биохимические исследования природной пыльцы, то есть пыльцы, полученной при ручном сборе цветов, подтверждают, что пыльцевые зерна имеют очень богатый состав по сравнению с другими клетками растительного организма. В настоящее время растет интерес к использованию пыльцы в различных областях, особенно в области медицины и косметологии, благодаря не только ее высокой калорийности и питательной ценности, но и содержанию природных соединений с антибактериальными и другими эффектами (Brovarskij and Brindza, 2010). К предполагаемым и хорошо подтвержденным биологическим свойствам пыльцы принадлежат антибиотическое, антиоксидантное, противовоспалительное, гиполипидемическое (антисклеротическое), антипростатическое, антигепатотоксическое, а также антидотное (после интоксикации сильными токсинами) и антианемическое действия. В последние годы обнаружены и изучены (в основном в испытаниях на животных) другие свойства пыльцы: иммунорегулирующие, иммуносупрессивные, антиаллергенные, противоопухолевые, антиангиогенные (подавляет рост новых кровеносных сосудов), обезболивающие при действии на нервную систему и мочевыводящие пути, а также замедление старения человеческого тела (Kedzia and Holderna-Kedzia, 2012).

Различия в питательной ценности предопределяют специфичность химического состава пыльцевых зерен каждого из видов растений. Также биохимический состав пыльцы зависит и от условий произрастания растений (почвенные и климатические условия, особенно во время роста и созревания пыльцы в пыльниках) и физиологической степени зрелости пыльцы (Brovarskij and Brindza, 2010). В процессе развития и созревания в пыльце происходит ряд цитохимических изменений. Ее биологическая ценность зависит от продолжительности и способа хранения, в течение которых может произойти нежелательное изменение биохимического состава. В значительной степени верно и то, что содержание химических веществ богаче в пыльце энтомофильных растений по сравнению с пыльцой анемофильных. В последние годы биохимические исследования проводятся чаще с пчелиной пыльцой, то есть пыльцой, собранной и обработанной пчелами (Brovarskij and Brindza, 2010).

Береза бородавчатая (Betula verrucosa Ehrh., син. B. pendula Roth.) принадлежит к ветроопыляемым растениям. Ее пыльца - частый объект научных исследова- ний, посвященных изучению аллергенных свойств, моделированию для прогнозирования распространения пыльцы, создания рекомбинантных аллергенов и экологической оценки состояния урбанизированных территорий (палиноиндикация) (Emilson et al., 1996; EI-Ghazaly et al., 1999; Cotos-Yáñez et al., 2004; Mothes and Valenta, 2004; Dzjuba, 2006; Pomes, 2008; Puc, 2012). Но человек с древнейших времен использовал пыльцу растений в своем рационе, и только с середины XIX века пыльца в воздухе была признана вредной для здоровья многих людей (Stanley and Linskens, 1974).

Пыльца березы - природный концентрат витаминов, микроэлементов и фитонцидов, благодаря чему является ценным продуктом питания и лечебным средством (Mironenko, 2002). Danikov (1993) обобщил многовековой опыт официальной и народной медицины. В книге «Дерево жизни. Все о целебных свойствах березы» он описывает целебные свойства березовой пыльцы. Это исключительно сильное целебное средство, регулирующее функции пищеварительного тракта, психическое состояние, помогающее при сильном истощении, эффективное при анемии и простатите. Пыльца березы прекрасный антибиотик, обладающий способностью останавливать развитие многих микроорганизмов, с трудом поддающихся уничтожению и являющихся возбудителями многих кишечных заболеваний. Пыльца известное косметическое средство. Экстракт соцветий березы содержит вещества с тромбопластической активностью. В эксперименте на животных он проявляет кровоостанавливающее действие и рассматривается как перспективное гемостатическое средство. Настойку мужских (тычиночных соцветий) применяют при заболеваниях сердца, язвенной болезни желудка, гастритах, экземах, фурункулезе и анемии (Kucik and Zuzuk, 2001). Предсезонное употребление меда с березовой пыльцой чувствительными к ней пациентами рассматривается как дополнительный метод лечения аллергических заболеваний (Saarinen et al., 2011).

Для конкретного использования пыльцы должен быть оценен состав биологически активных компонентов. Антиоксидантная активность - один из способов оценки биологической активности (Lubsandorzhieva, 2009; Graikou et al., 2011; Pascoal et al., 2014). Интерес в определении антиоксидантной активности различных веществ растительного происхождения увеличивается (Brovarskij and Brindza, 2010). Антиоксидантами являются витамины $E, C$, каротиноиды, флавоноиды и другие вещества фенольной природы (Antal, 2010; Sen et al., 2011). Зачастую определяют общую антиоксидантную активность (ОАА) при совместном действии составных вещества. Согласно Campos et al. (2003), антиоксидантная активность пыльцы в значительной степени - результат действия фенольных соединений и флавоноидов, которые обладают способностью поглощать сво- 
бодные радикалы (хотя и другие составляющие, такие как белки и витамины, могут также усиливать это свойство). Другие внешние факторы (растворитель, используемый для экстракции, продолжительность экстракции и методы хранения пыльцы) играют важную роль в регистрации биологической активности (Chantarudee et al., 2012). Сильная антиоксидантная активность, наблюдаемая in vitro, не может адекватно проявляться в условиях in vivo (Campos et al., 2003; Brovarskij and Brindza, 2010).

Методы определения антиоксидантной активности подразделяются на две большие группы: (1) основанные на ликвидации радикалов и (2) основанные на оценке окислительно-восстановительных свойств веществ (Brovarskij and Brindza, 2010). К первой группе относится метод с использованием стабильного радикала ДФПГ (2,2-дифенил-1-пикрилгидразил), который рассматривается как одна из основных методик оценки антирадикальной активности продуктов пчеловодства (Campos et al., 2003; Lee et al., 2009; LeBlanc et al., 2009; Brovarskij and Brindza, 2010; Basuny et al., 2013). Метод основан на учете передачи электронов от антиоксиданта свободному радикалу ДФПГ, который при этом изменяет свою окраску с фиолетовой на желтую, что фиксируется спектрофотометрически (Saeheng et al., 2012).

С целью определения биологической активности зрелой пыльцы $B$. verrucosa Ehrh. исследованы содержание белков и жирнокислотный состав липидов, определена общая антиоксидантная активность водных, этаноловых и метаноловых экстрактов пыльцы из различных мест произрастания. Ранее авторы сообщали о частично проведенных исследованиях антиоксидантной активности пыльцы березы бородавчатой (Shevcova et al., 2012). Исследование было расширено.

\section{Материал и методы исследований}

\section{Растительный материал}

Пыльца B. verrucosa Ehrh. заготовлена на территории Украины до начала пыления в период с 18 по 24 апреля 2011 г. и на территории Словакии в период с 15 по 21 апреля 2013 г. Выбор мест заготовки пыльцы березы бородавчатой основывался на подборе различных условий роста деревьев, степени антропогенной нагрузки, принадлежности к различным «чернобыльским зонам» на территории Украины, а также относительно близком расположении друг от друга для возможности заготовки образцов пыльцы в период цветения березы бородавчатой. Всего заготовлено 7 украинских образцов пыльцы и 3 словацких: BV1 - г. Киев (пыльца собрана с берез, растущих в парковой зоне); BV2a и BV2b - г. Переяслав-Хмельницкий Киевской обл., расположен на расстоянии 112 км на юго-запад от г. Киев (образец BV2a заготовлен на территории жилого массива вблизи автомобильных дорог; образец BV2b - на территории Музея народной архитектуры и быта под открытым небом как контрольный); BV3 - с. Хоцки Киевской обл. в 120 км юго-западнее г. Киев (пыльца собрана с берез, растущих на отдельных полянах в лесу; также считали контрольным образцом); BV4 - пгт. Иванков Киевской обл., относящийся к III чернобыльской зоне согласно данным
Министерства по вопросам чрезвычайных ситуаций и защите населения от последствий Чернобыльской катастрофы Украины (2008) и находится в 80 км северозападнее г. Киев (пыльца собрана с берез, растущих возле автомобильных дорог и жилых домов); BV5 - г. Кузнецовск Ривненской обл., относящийся к IV чернобыльской зоне, расположен на расстоянии 339 км к западу от г. Киев (пыльца собрана с берез, растущих возле леса вблизи автомобильной трассы). На территории города функционирует Ривненская атомная электростанция; BV6 - аэродром «Бородянка» 2 км к северу от пгт. Бородянка Киевской обл., также относится к IV чернобыльской зоне, расположен на расстоянии 30 км на северо-запад г. Киев (пыльца собрана с берез, растущих возле аэродрома). Словацкие образцы пыльцы заготовлены в г. Нитра, Нитранский край: BV7 - пыльца собрана с березы, растущей возле автомобильной дороги; BV8 - пыльца собрана с березы на территории Ботанического сада Словацкого аграрного университета; BV9 пыльца собрана с берез на территории жилого массива вблизи автомобильных дорог.

Пыльцу сушили при комнатной температуре в тени и сохраняли в морозильной камере при температуре $-7^{\circ} \mathrm{C}$.

\section{Определение состава белков}

Для исследования состава белков образцы пыльцы были направлены в экологическую лабораторию EL spol. s r.o., Spišská Nová Ves, Словакия. Их содержание определяли по общепринятому методу Кьельдаля. Результаты представлены в форме $x \pm S x$.

\section{Определение жирнокислотного состава липидов}

Исследование проводили в Институте проблем патологии при Национальном медицинском университете имени А.А. Богомольца. Жирнокислотный состав липидов определяли методом газожидкостной хроматографии (Gubs'kyj et al., 2005). Навеску пыльцы березы бородавчатой 0,3-0,5 г переносили в мерную пробирку объемом 10 мл и заливали экстрагирующей смесью. Общие липиды тканей экстрагировали 5 мл хлороформметаноловой смесью в соотношении $2: 1$ и выдерживали 30 мин в холодильнике. Для лучшего распределения фаз добавляли 1 мл дистиллированной воды. Далее отбирали хлороформную нижнюю фазу пипеткой Пастера. Для полной реакции этап экстракции повторяли дважды. Объединенные хлороформные экстракты концентрировали выпариванием к объему одной капли под струей газообразного азота при температуре $45{ }^{\circ} \mathrm{C}$ на водяной бане. Для проведения гидролиза и метилирования высших жирных кислот липидов тканей к сухому осадку липидов добавляли 5 мл $1 \% \mathrm{H}_{2} \mathrm{SO}_{4}$ в метаноле. Раствор переносили в стеклянную ампулу емкостью 10 мл. После запайки проводили гидролиз и метилирование в термостате при температуре $85{ }^{\circ} \mathrm{C}$ в течение 20 мин. Экстракцию этилированных жирных кислот проводили дважды гексан-эфирной смесью в соотношении 1 : 1 в количестве 5 мл. Для разделения фаз добавляли 1 мл дистиллированной воды. Отбирали верхнюю фазу пипеткой Пастера. Объединенные экстракты упаривали досуха в токе азота при температуре $45{ }^{\circ} \mathrm{C}$ на водяной бане. Сухой осадок растворяли в 40-50 мкл чистого гексана и вводили в испаритель хроматографа серии «Цвет- 
500» в количестве 5 мкл. Для определения спектра жирных кислот липидов использовали стеклянную колонку (3,0 м x 0,3 см), заполненную фазой 5\% полиэтиленгликоль сукцината на хромотоне N-AW-HMDS (зернирование 0,125-0,160 мм) при температурах: колонки $190{ }^{\circ} \mathrm{C}$, испарителя $-250{ }^{\circ} \mathrm{C}$, при затратах азота и водорода - 35 мл/мин, воздуха - 200 мм/ч.

Количественную оценку спектра жирных кислот липидов проводили методом нормирования путем измерения площади пиков этилированных производных жирных кислот и определения их состава в процентах (\%). Ошибка определения составляет $10 \%$.

\section{Определение общей антиоксидантной активности}

Исследование проводили в Институте сохранения биоразнообразия и биологической безопасности при Словацком аграрном университете в Нитре. Общую антиоксидантную активность пыльцы оценивали по уровню свободных радикалов, после реакции ДФПГ $\left(C_{18} H_{12} N_{5} O_{6}, M=394,33\right), 0,025$ г растворенного в 100 мл метанола, с образцом пыльцы березы бородавчатой по модифицированной методике Y.-T. Kaо (Kaо et al., 2011). Для приготовления экстрактов использовали три растворителя: дистиллированную воду комнатной температуры, 100\% метанол и 70\% этанол. Такие концентрации метанола и этанола были выбраны в результате анализа информации из литературных источников (Carpes et al., 2007; LeBlanc et al., 2009; Agadzhanjan et al., 2009). Пыльцу каждого образца (5 г) растворяли в 100 мл растворителя в течение 2 ч перемешиванием на механической мешалке Kavalier LT-2. Время оптимальной экстракции было подобрано путем серии экспериментов. После экстракции и фильтрации экстракта, надосадочную жидкость в количестве 0,1 мл смешивали с рабочим раствором ДФПГ в количестве 3,9 мл и измеряли кинетику реакции фотоколориметрическим методом на спектрофотометре серии «Genesys 20», модель 4001/4. Метаноловый раствор ДФПГ имеет интенсивное фиолетовое окрашивание с максимумом поглощения при длине волны 515 нм. В результате реакции фиолетовая окраска переходит в светло-желтую. Результат фиксировали через 10 мин протекания реакции в темноте. Процент общей антиоксидантной активности (ОАА)

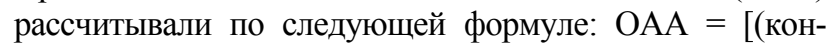
троль - образец) / контроль] $100 \%$.

Все измерения ОАА проводили в пятикратной повторности. Математическую обработку результатов измерений осуществляли по общепринятым методикам (Urbah, 1963). При анализе данных использовали методы дисперсионного анализа (ANOVA), а для оценки значимых различий между средними значениями (сравнение значений) на уровне $P<0,05$ использовали тест Тьюки.

\section{Результаты и их обсуждение}

Пыльцевые зерна, из-за своих биологических функций, состоят из широкого спектра молекул. Они варьируют от очень устойчивого биополимера спорополенина, в значительной степени неизвестного по составу и структуре, до флавоноидов, пигментов и наполняющих клетку внутри белков, липидов, углеводов и нуклеино- вых кислот (Schulte et al., 2008). Пыльца особенно богата легкоусваиваемым белком и незаменимыми аминокислотами. Содержание белка определяется генотипом и меняется в зависимости от видов растений (Campos et al., 2008; Özler et al., 2009). Также содержание белка в пыльце одного вида может отличаться в зависимости от погоды, почвы и других факторов окружающей среды (табл. 1 и 2). Типичный диапазон содержания белка в пыльце, собранной вручную и пчелами, составляет 7,5$35,0 \%$, хотя было определено содержание белка и более 40\% (Bogdanov, 2004; Brovarskij and Brindza, 2010). Пыльцевая аллергия обусловлена белками или гликопротеинами, присутствующими в пыльцевой стенке и цитоплазме. Белки пыльцы сохраняются в слоях пыльцевой стенки (экзине и интине) (El-Ghazaly et al., 1995, 1999; Özler et al., 2009).

Таблича 1

Содержание белка (\%) в пыльце Betula verrucosa Ehrh.

\begin{tabular}{|c|c|c|c|c|c|c|c|c|c|}
\hline BV1 & BV2a & BV2b & BV3 & BV4 & BV5 & BV6 & BV7 & BV8 & BV9 \\
\hline 23,8 & 21,5 & 25,1 & 22,6 & 23,1 & 25,6 & 21,8 & 17,8 & 24,4 & 21,2 \\
$\pm 1,0$ & $\pm 1,0$ & $\pm 1,0$ & $\pm 1,0$ & $\pm 1,0$ & $\pm 1,0$ & $\pm 1,0$ & $\pm 1,0$ & $\pm 1,0$ & $\pm 1,0$ \\
\hline
\end{tabular}

Примечание: коэффициент вариации равен в среднем $8 \%$.

Таблий 2

Сравнение результатов определения белка (\%) в пыльце Betula verrucosa Ehrh. с литературными данными

\begin{tabular}{|l|c|}
\hline \multicolumn{1}{|c|}{ Источник } & Среднее \\
\hline Наши результаты, 2013 & $22,70 \pm 2,28$ \\
\hline Přidal, 2003 & 23,02 \\
\hline Özler et al., 2009 & 7,73 \\
\hline $\begin{array}{l}\text { Hopмa для сухой пыльцы пчелиной } \\
\text { (Campos et al., 2008) }\end{array}$ & $10-40$ \\
\hline
\end{tabular}

Содержание белка в пыльце $B$. verrucosa варьирует в пределах 17,85-25,62\% в зависимости от места произрастания. Данные соответствуют литературным и норме для пыльцы пчелиной. Меньше всего белка определено в образце из Словакии, который заготовлен вблизи автомобильной дороги в городе (BV7), а больше всего - в образце пыльцы из Украины, который также заготовлен вблизи автомобильной трассы, но возле леса (BV5).

Качество белка пыльцы зависит от количества незаменимых аминокислот (Nicolson and Human, 2013). Özler et al. (2009) провел сравнительный анализ содержания свободных аминокислот в пыльце $B$. pendula, в том числе, заготовленной в г. Анкара (Турция) в 2000 и 2008 гг. В целом он определил 21 аминокислоту. Примечательным в полученных результатах является то, что нет четкой тенденции снижения или увеличения количества аминокислотного состава со временем в различных видах. Содержание свободных аминокислот свежих и сохраненных пыльцевых зерен показывает уникальные изменения в каждом виде (Özler et al., 2009).

Процессы прорастания пыльцы и роста пыльцевой трубки обеспечиваются активизацией многих биохимических процессов, в том числе и липидного обмена, поскольку липиды и составляющие их жирные кислоты служат важным источником энергии. После попадания пыльцы на рыльце пестика жирные кислоты (ЖК) выполняют субстратную или энергетическую роль, а также 
принимают участие в синтезе веществ, обеспечивающих рост пыльцевой трубки. У березы процесс цветения опережает формирование вегетативной сферы, поэтому фертильность пыльцы и способность ее к прорастанию в значительной мере зависят от состояния мембран и их сохранения (Vetchinnikova et al., 2012). Липиды являются основными компонентами экзины пыльцы (D'Amatol et al., 2007). Липиды играют важную роль как в формировании устойчивости растений к низким температурам, так и в соответствующих реакциях растений на биотический стресс (Lavrova et al., 2012). Способность клеток адаптироваться к низким температурам связывают с возможностью синтезировать de novo ненасыщенные жирные кислоты, в том числе линоленовую, которая повышает текучесть липидного бислоя и предотвращает фазовое разделение липидов под действием низких температур (Graskova et al., 2011; Vetchinnikova et al., 2012).
В зрелой пыльце Betula L. содержание суммарных липидов варьирует от 32 до 52 мг/Г сухого вещества. По составу суммарные липиды пыльцы представлены как нейтральными (запасными) липидами, так и полярными (фосфо- и гликолипидами), которые являются структурной основой мембран (Vetchinnikova et al., 2012). В суммарных липидах образцов пыльцы березы бородавчатой выявлено 8 компонентов с числом углеродных атомов от 14 до 20, представленных как насыщенными, так и ненасыщенными жирными кислотами (ЖК). Среди насыщенных ЖК преобладает пальмитиновая, среди ненасыщенных - олеиновая и линолевая кислоты (табл. 3). Преобладание этих ЖК также характерно для пчелиной пыльцы, так как олеиновая и пальмитиновая кислоты играют важную роль в питании пчелы, а линолевая обладает антимикробной и противогрибковой активностью (Brovarskij and Brindza, 2010; Nicolson and Human, 2013).

Жирнокислотный состав липидов (\%) пыльцы Betula verrucosa Ehrh.

Таблица 3

\begin{tabular}{|l|c|c|c|c|c|c|c|c|c|c|c|c|c|}
\hline \multicolumn{1}{|c|}{ Название ЖК } & BV1 & BV2a & BV2b & BV3 & BV4 & BV5 & BV6 & BV7 & BV8 & BV9 & $\begin{array}{c}x \pm S_{x} \\
\text { BV1-BV6 }\end{array}$ & $\begin{array}{c}x \pm S_{x} \\
\text { BV7-BV9 }\end{array}$ & $\begin{array}{c}x \pm S_{x} \\
\text { BV1-BV9 }\end{array}$ \\
\hline Миристиновая, $\mathrm{C}_{14: 0}$ & 2,9 & 2,4 & 1,7 & 1,8 & 1,8 & 1,4 & 2,1 & 3,0 & 1,9 & 6,5 & $2,0 \pm 0,5$ & $3,8 \pm 2,4$ & $2,6 \pm 1,5$ \\
\hline Пентадекановая, $\mathrm{C}_{15: 0}$ & 0,3 & 0,2 & 0,4 & 0,3 & 0,3 & 0,3 & 0,3 & 1,5 & 0,7 & 3,3 & $0,3 \pm 0,1$ & $1,8 \pm 1,3$ & $0,8 \pm 1,0$ \\
\hline Пальмитиновая, $\mathrm{C}_{16: 0}$ & 36,3 & 34,6 & 32,4 & 34,4 & 32,0 & 31,5 & 32,7 & 34,8 & 37,6 & 32,7 & $33,4 \pm 1,7$ & $35,0 \pm 2,5$ & $33,9 \pm 2,0$ \\
\hline Стеариновая, $\mathrm{C}_{18: 0}$ & 4,8 & 4,9 & 4,6 & 3,6 & 4,2 & 4,2 & 4,5 & 3,0 & 3,8 & 3,9 & $4,4 \pm 0,4$ & $3,6 \pm 0,5$ & $4,2 \pm 0,6$ \\
\hline Олеиновая, $\mathrm{C}_{18: 1}$ & 25,6 & 24,4 & 26,8 & 27,4 & 28,8 & 25,6 & 34,4 & 38,8 & 30,0 & 32,7 & $27,6 \pm 3,3$ & $33,8 \pm 4,5$ & $29,5 \pm 4,6$ \\
\hline Линолевая, $\mathrm{C}_{18: 2}$ & 28,6 & 31,6 & 32,9 & 30,8 & 31,5 & 35,6 & 24,5 & 17,9 & 25,2 & 19,6 & $30,8 \pm 3,5$ & $20,9 \pm 3,8$ & $27,8 \pm 5,9$ \\
\hline Линоленовая, $\mathrm{C}_{18: 3}$ & 1,2 & 1,2 & 0,7 & 1,4 & 1,1 & 1,1 & 1,2 & 0,5 & 0,4 & 0,7 & $1,1 \pm 0,2$ & $0,5 \pm 0,2$ & $1,0 \pm 0,3$ \\
\hline Арахидоновая, $\mathrm{C}_{20: 4}$ & 0,3 & 0,2 & 0,4 & 0,3 & 0,3 & 0,3 & 0,3 & 0,5 & 0,3 & 0,6 & $0,3 \pm 0,1$ & $0,5 \pm 0,2$ & $0,4 \pm 0,1$ \\
\hline$\sum$ НЖК & 44,3 & 42,1 & 39,1 & 40,1 & 38,3 & 37,4 & 39,6 & 42,3 & 44,0 & 46,4 & $40,1 \pm 2,4$ & $44,2 \pm 2,1$ & $41,4 \pm 2,9$ \\
\hline$\sum$ ННЖК & 55,7 & 57,4 & 60,8 & 59,9 & 61,7 & 62,6 & 60,4 & 57,7 & 55,9 & 53,6 & $59,8 \pm 2,4$ & $55,7 \pm 2,1$ & $58,6 \pm 3,0$ \\
\hline$\sum$ ПНЖК & 30,1 & 33,0 & 34,0 & 32,5 & 32,9 & 37,0 & 26,0 & 18,9 & 25,9 & 20,9 & $32,2 \pm 3,4$ & $21,9 \pm 3,6$ & $29,1 \pm 6,0$ \\
\hline
\end{tabular}

Примечание: $\sum$ НЖК - сумма насыщенных жирных кислот, $\sum$ ННЖК - сумма ненасыщенных жирных кислот, $\sum$ ПНЖК сумма полиненасыщенных жирных кислот; $x \pm S_{x}$ - среднее значение \pm стандартное отклонение

Vetchinnikova et al. (2012) получила аналогичные peзультаты по преобладанию среди насыщенных ЖК пальмитиновой кислоты, а среди ненасыщенных - линолевой. Из таблицы 3 также видно, что содержание ненасыщенных ЖК $(58,6 \pm 2,95)$ преобладает над содержанием насыщенных ЖК $(41,4 \pm 2,93)$.

Среди украинских образцов пыльцы березы бородавчатой наиболее высокая вариабельность содержания установлена для линолевой $(24,5-35,6 \%)$ и олеиновой (24,4-34,4\%) кислот, наименьшая - для пентадекановой и арахидоновой кислот $(0,2-0,4 \%)$. Наибольшие значения вариабельности характеризуют образцы BV6-BV5 и BV2a-BV6, наименьшие - BV2a-BV2b. Среди словацких образцов пыльцы березы бородавчатой наиболее высокая вариабельность содержания также установлена для олеиновой $(30,0-38,8 \%)$ и линолевой $(17,9-25,2 \%)$ кислот, наименьшая - для линоленовой $(0,4-0,7 \%)$ и арахидоновой $(0,3-0,6 \%)$. Наибольшие значения вариабельности у образцов BV8-BV7 и BV7-BV8, наименьшие - BV8-BV9. Значительная разница в жирнокислотном составе украинской и словацкой пыльцы отмечена для средних значений насыщенных кислот (миристиновой и пентадекановой) с преобладанием содержания в словацких образцах пыльцы березы бородавчатой, стеариновой - в украинских. Из ненасыщенных олеиновой больше в словацкой пыльце, а линолевой - в украин- ской, из полиненасыщенных линоленовой кислоты больше в украинской пыльце, арахидоновой почти одинаково (см. табл. 3). В целом образцы украинской пыльцы $B$. verrucosa имеют больше полиненасыщенных жирных кислот, чем словацкие. По результатам жирнокислотного состава липидов, как и белков, отличается образец BV5, который имеет наивысшие показатели $\sum$ ННЖК и $\sum$ ПНЖК, а BV7 - низкое содержание ПНЖК.

Олеиновая кислота в дальнейшем может приводить к изменениям функционального состояния мембран растения, поскольку является субстратом для синтеза линолевой и линоленовой ЖК (Los', 2005). Длинноцепочечные ненасыщенные ЖК в пыльце, линолевая и линоленовая, служат предшественниками для биосинтеза ряда гормонов растений - фитопростанов (D'Amatol et al., 2007; Kapustin et al., 2013). Наибольшее количество фитопростаноидов $F_{l}$ (32 мкг/г) найдено в свежей пыльце березы белой (Betula alba L.). В период прорастания в почках древесных растений (тополь, береза, лиственница) содержание простагландинов увеличивается, что может свидетельствовать об их участии в ростовых процессах растений. Уровень эндогенных простагландинов увеличивается в различных условиях, связанных с повышением генерации свободных радикалов (биотический и абиотический стрессы). Скорее всего, под действием стресса происходит образование активных форм кислорода, кото- 
рые вызывают процессы неэнзиматического окисления линоленовой и других ненасыщенных жирных кислот и образование фитопростанов (Filipcova et al., 2011).

Антиоксидантная способность пыльцы естественно очень высока (Brovarskij and Brindza, 2010), что характерно и для пыльцы B. verrucosa (табл. 4). Исходя из полученных результатов и литературных данных, пыльца березы бородавчатой имеет антиоксиданты в своем составе.

Считается, что антирадикальная способность пыльцы уменьшается со временем (Brovarskij and Brindza, 2010). Исследования ОАА для словацких образцов проводились через месяц после сбора и хранения пыльцы, для украинских образцов - через год. Результаты по OAА в целом высоки. Значения ОАА для водных экстрактов колеблются в пределах 74,8-85,5\%, для этаноловых - 60,3-95,0\%, для метаноловых - 46,1-92,6\%. Самая большая разница в полученных значениях ОАА наблюдается для метаноловых экстрактов пыльцы, наименьшая - для водных экстрактов. В целом результаты для водных экстрактов ОАА наиболее стабильны. Согласно тесту средних Тьюки образцы поделены на пять групп, которые достоверно отличаются между собой (см. табл. 4). Наивысшая ОАА водных экстрактов пыльцы принадлежит двум контрольным образцам BV2b и BV3 (из музея и леса) и BV4 и BV5 (пыльца деревьев, растущих возле автомобильной дороги в жилом районе и возле прилесной автомобильной трассы). Значения OAА водных и этаноловых экстрактов украинских образцов достоверно отличаются от словацких. ОАА водных экстрактов украинских образцов пыльцы березы бородавчатой больше, чем словацких, в случае этаноловых - наоборот. Исходя из этих данных, можно предположить, что вещества, которые обеспечивают антиоксидантную активность пыльцы березы бородавчатой, отличаются по своей природе, а условия произрастания влияют на их синтез. Свободные радикалы могут поглощать белки (Campos et al., 2003). Образец пыльцы березы бородавчатой с наибольшим содержанием белков (BV5) имеет наибольшее значение ОАA среди водных экстрактов, образец с наименьшим содержанием белков (BV7) - наименьшее. Коэффициент корреляции между содержанием белка и ОАА водных экстрактов пыльцы березы бородавчатой составляет 0,70, для этаноловых и метаноловых экстрактов всего лишь $-0,26$ и 0,22 соответственно. Можно предположить, что водорастворимые белки в пыльце $B$. verrucosa участвуют в защитной системе пыльцы. Украинские и словацкие образцы пыльцы березы бородавчатой отличаются и по жирнокислотному составу липидов, что обсуждалось выше.

Таблица 4

Общая антиоксидантная активность (\%) водных, этаноловых и метаноловых экстрактов пыльцы Betula verrucosa Ehrh.

\begin{tabular}{|c|c|c|c|c|c|c|}
\hline \multirow{2}{*}{ Образцы } & \multicolumn{2}{|c|}{ Водный экстракт } & \multicolumn{2}{|c|}{ Этаноловый экстракт } & \multicolumn{2}{|c|}{ Метаноловый экстракт } \\
\cline { 2 - 7 } & $x \pm S_{x}$ & $V, \%$ & $x \pm S_{x}$ & $V, \%$ & $x \pm S_{x}$ & $V, \%$ \\
\hline BV1 & $81,9^{\mathrm{ab}} \pm 0,67$ & 0,82 & $64,6^{\mathrm{d}} \pm 1,95$ & 3,02 & $46,1^{\mathrm{e}} \pm 0,84$ & 1,81 \\
\hline BV2a & $80,5^{\mathrm{b}} \pm 0,90$ & 1,11 & $67,9^{\mathrm{d}} \pm 1,04$ & 1,53 & $74,7^{\mathrm{c}} \pm 0,65$ & 0,87 \\
\hline BV2b & $84,1^{\mathrm{a}} \pm 1,78$ & 2,12 & $70,8^{\mathrm{d}} \pm 2,06$ & 2,91 & $79,4^{\mathrm{b}} \pm 0,66$ & 0,83 \\
\hline BV3 & $84,1^{\mathrm{a}} \pm 1,07$ & 1,28 & $60,3^{\mathrm{e}} \pm 3,18$ & 5,27 & $51,4^{\mathrm{d}} \pm 0,97$ & 1,88 \\
\hline BV4 & $85,5^{\mathrm{a}} \pm 0,93$ & 1,08 & $75,1^{\mathrm{c}} \pm 1,16$ & 1,54 & $92,6^{\mathrm{a}} \pm 0,67$ & 0,72 \\
\hline BV5 & $84,7^{\mathrm{a}} \pm 0,72$ & 0,85 & $84,9^{\mathrm{b}} \pm 0,89$ & 1,05 & $92,4^{\mathrm{a}} \pm 0,57$ & 0,61 \\
\hline BV6 & $82,7^{\mathrm{ab}} \pm 2,43$ & 2,94 & $69,3^{\mathrm{d}} \pm 2,60$ & 3,76 & $78,8^{\mathrm{b}} \pm 0,57$ & 0,72 \\
\hline BV7 & $74,8^{\mathrm{d}} \pm 0,43$ & 0,57 & $95,0^{\mathrm{a}} \pm 0,28$ & 0,29 & $91,6^{\mathrm{a}} \pm 0,43$ & 0,47 \\
\hline BV8 & $78,4^{\mathrm{bc}} \pm 1,10$ & 1,40 & $95,0^{\mathrm{a}} \pm 3,34$ & 3,51 & $72,0^{\mathrm{c}} \pm 4,33$ & 6,01 \\
\hline BV9 & $78,1^{\mathrm{bc}} \pm 0,57$ & 0,74 & $95,4^{\mathrm{a}} \pm 0,51$ & 0,53 & $91,5^{\mathrm{a}} \pm 0,39$ & 0,43 \\
\hline
\end{tabular}

Примечание: $x \pm S_{x}$ - среднее значение \pm стандартное отклонение, $V$ - коэффициент вариации (\%), a, b, с, ... - ранжирование средних значений согласно тесту средних Тьюки $(P<0,05)$; одинаковые буквы в пределах колонки указывают на недостоверную разницу между средними значениями.

Следовательно, химический состав индивидуален и зависит от вида растений. В случае пыльцы $B$. verrucosa, собранной искусственно, она имеет характеристики одного источника, стабильный состав, определенную степень чистоты и зрелости. Влияние географического и климатического факторов следует исключить для всех украинских образцов между собой и всех словацких. Места сбора пыльцы березы бородавчатой в Украине расположены в пределах $49^{\circ} 54^{\prime}-51^{\circ} 27^{\prime}$ с. ш., значения метеорологических показателей почти не отличались на протяжении исследуемого периода. Город Нитра на территории Словацкой республики находится на $48^{\circ} 18^{\prime}$ с. ш., но погодные условия более мягкие по сравнению с украинскими местами сбора. Это отображается на дате начала цветения. Не исключено влияние эдафического фактора и фактора времени. Только свежая пыльца имеет оптимальную биологическую активность (Bogdanov, 2004). Разные методы анализа и лаборатории также мо- гут повлиять на полученные данные (Nicolson and Human, 2013). Но в наибольшей степени, авторы считают, влияет местонахождение вида, которое определяет совокупность условий абиотической и биотической среды. При анализе данных выбросов в атмосферный воздух от стационарных и передвижных источников исследуемых пунктов в загрязнении окружающей среды отмечена лидирующая роль автотранспорта. Образцы пыльцы березы бородавчатой BV2a, BV4, BV5, BV7, BV9 заготовлены с учетом влияния этого фактора. Можно отметить, что нет четкой зависимости между полученными результатами. Среди образцов пыльцы из Украины выделяется образец BV5 (г. Кузнецовск Ривненской обл.) от всех остальных из Киевской области. Все словацкие образцы пыльцы соответственно отличаются от украинских, что подтверждено отличиями в жирнокислотном составе липидов и разницей ОАА водных и этаноловых экстрактов. 


\section{Выводы}

В 10 образцах пыльцы $B$. verrucosa из разных мест произрастания отмечено наибольшее содержание пальмитиновой, линолевой и олеиновой кислот, характерно преобладание ненасыщенных жирных кислот. Исследование обшей антиоксидантной активности водных, этаноловых и метаноловых экстрактов показало, что пыльца березы бородавчатой является хорошим поглотителем ДФПГ in vitro. Водные вытяжки пыльцы березы бородавчатой наиболее стабильны. Вариации химического состава пыльцы отражают различия в условиях окружающей среды в ходе созревания растений.

\section{Благодарности}

Работа выполнена в рамках проекта «26220220180 Строительство научно-исследовательского центра “Агробиотех”» при финансовой поддержке Европейского фонда регионального развития - Оперативная программа по исследованиям и развитию. Экспериментальные исследования реализованы в лабораториях Научного центра сохранения агробиоразнообразия и его использования Факультета агробиологии и продовольственных ресурсов при Словацком аграрном университете в г. Нитра.

\section{Библиографические ссылки}

Agadzhanjan, V.S., Ligaj, L.V., Mucueva, S.H., 2009. Izuchenie himicheskogo sostava summarnoj kompozicii antioksidantov, poluchennoj iz mjakoti tykvy obyknovennoj (Cucurbita pepo L.). Sovremennye problemy nauki i obrazovanija (prilozhenie «Farmacevticheskie nauki») 6, 3.

Antal, D.S., 2010. Medicinal plants with antioxidant properties from Banat region (Romania): A rich pool for the discovery of multi-target phytochemicals active in free-radical related disorders. Analele Universităţii din Oradea - Fascicula Biologie 17(1), 14-22.

Basuny, A.M., Arafat, S.M., Soliman, H.M., 2013. Chemical analysis of olive and palm pollen: Antioxidant and antimicrobial activation properties. Herald Journal of Agriculture and Food Science Research 2(3), 91-97.

Bogdanov, S., 2004. Quality and Standards of Pollen and Beeswax. Apiacta 38, 334-341.

Brovarskij, V., Brindza, J., 2010. Včelí obnôžkový pel'. FOP I. S., Maidachenko.

Campos, M.G.R., Bogdanov, S., Bicudo de Almeida-Muradian, L., Szczesna, T., Mancebo, Y, Frigerio, C., Ferreira, F., 2008. Pollen composition and standardisation of analytical methods. Journal of Apicultural Research and Bee World 47(2), 156-163.

Carpes, S.T., Begnini, R., de Alencar, S.M., Masson, M.L., 2007. Study of preparations of bee pollen extracts, antioxidant and antibacterial activity. Ciênc. Agrotec., Lavras 31(6), 1818-1825.

Carpes, S.T., Mourão, G.B., de Alencar, S.M., Masson, M.L., 2009. Chemical composition and free radical scavenging activity of Apis mellifera bee pollen from Southern Brazil. Braz. J. Food Technol. 12(3), 220-229.

Chantarudee, A., Phuwapraisirisan, P., Kimura, K., Okuyama, M., Mori, H., Kimura, A., Chanchao, C., 2012. Chemical constituents and free radical scavenging activity of corn pollen collected from Apis mellifera hives compared to floral corn pollen at Nan, Thailand. BMC Complement. Altern. Med. 12, 45-57.

Cotos-Yáñez, R.T., Rodríguez-Rajo, F.J., Jato, M.V., 2004 Short-term prediction of Betula airborne pollen concentration in Vigo (NW Spain) using logistic additive models and partially linear models. Int. J. Biometeorol. 48, 179-185.

D'Amatol, G., Cecchi, L., Bonini, S., Nunes, C., AnnesiMaesano, I., Behrendt, H., Liccardi, G., Popov, T., van Cauwenberge, P., 2007. Allergenic pollen and pollen allergy in Europe. Allergy 62, 976-990.

Dannikov, N.I., 1993. Derevo zhizni. Vse o celebnyh svojstvah berezy. Labirint, Moscow.

Dzjuba, O.F., 2006. Izuchenie pyl'cy iz poverhnostnyh prob dlja ocenki kachestva okruzhajushhej sredy. Neftegazovaja Geologija. Teorija i praktika 1, 1-18.

EI-Ghazaly, G., Moate, R., Cresti, M., Walles, B., Takahashi, Y., Ferreira, F., Obermeyer, G., 1999. Localization and release of allergens from tapetum and pollen grains of Betula pendula. Protoplasma 208, 37-46.

El-Ghazaly, G., Takahashi, Y., Nilsson, S., Grafström, E., Berggren, B., 1995. Orbicules in Betula pendula and their possible role in allergy. Grana 34, 300-304.

Emilson, A., Berggren, B., Svensson, A., Takahashi, Y., Scheynius, A., 1996. Localization of the major allergen Bet $\mathrm{v}$ I in birch pollen by confocal laser scanning microscopy. Grana 35, 199-203.

Filipcova, G.G., Lapkovskaja, E.M., Jurin, V.M., 2011. Rol' prostanoidov $\mathrm{v}$ reguljacii fiziologicheskih processov $\mathrm{v}$ rastenijah. Trudy BGU 6(2), 59-65.

Graikou, K., Kapeta, S., Aligiannis, N., Sotiroudis, G., Chondrogianni, N., Gonos, E., Chinou, I., 2011. Chemical analysis of Greek pollen - Antioxidant, antimicrobial and proteasome activation properties. Chem. Cent. J. 5, 33-42.

Graskova, I.A., Dudareva, L.V., Zhivet'ev, M.A., Stolbikova, A.V., Sokolova N.A., Vojnikov, V.K., 2011. Dinamika sezonnyh izmenenij zhirnokislotnogo sostava, stepeni nenasyshhennosti zhirnyh kislot i aktivnosti acil-lipidnyh desaturaz $\mathrm{v}$ tkanjah nekotoryh lekarstvennyh rastenij, proizrastajushhih v uslovijah Predbajkal'ja. Himija Rastitel'nogo Syr'ja 4, 223-230.

Gubs'kyj, J.I., Janic'ka, L.V., Brjuzgina, T.S., 2005. Zhyrnokyslotnyj sklad lipidiv golovnogo mozku shhuriv pry toksychnomu urazhenni 1,2-dyhloretanom ta vvedennja nikotynamidu. Suchasni Problemy Toksykologii' 1, 19-22.

Kao, Y.-T., Lu, M.-J., Chen, A.C., 2011. Preliminary analyses of phenolic compounds and antioxidant activities in tea pollen extracts. J. Food Drug Anal. 19(4), 470-477.

Kapustyn, M.A., Radevych, V.S., Kurchenko, V.P., Pashkovskyj, F.S., Lahvych, F.A., 2013. Poluchenye klatratov beta-cyklodekstryna s syntetycheskymy fytoprostanoydamy. Mezhdunar. nauchn. konf. "Byologycheski aktivnye veshhestva rastenyj - izuchenye i ispol'zovanie". Minsk 106-107 (in Russian).

Kedzia, B., Holderna-Kedzia, E., 2012. Nowe badania nad biologicznymi wlasciwosciami pylku kwiatowego. Postepy Fitoterapii 1, 48-54.

Kucik, R.V., Zuzuk, B. M., 2001. Bereza borodavchataja (Bereza povislaja). Analiticheskij obzor. Provizor 10, 21-25.

Lavrova, V.V., Sysoeva, M.I., Matveeva, E.M., 2012. Zhirnokislotnyj sostav lipidov list'ev kartofelja $\mathrm{v}$ uslovijah periodicheskoj i dlitel'noj gipotermii. Trudy Karel'skogo Nauchnogo Centra RAN 2, 91-96.

LeBlanc, B.W., Davis, O.K., Boue, S., DeLucca, A., Deeby, T., 2009. Antioxidant activity of Sonoran desert bee pollen. Food Chem. 115, 1299-1305.

Lee, K.H., Kim, A.J., Choi, E.M., 2009. Antioxidant and antiinflammatory activity of pine pollen extract in vitro. Phytother. Res. 23, 41-48. 
Los', D.A., 2005. Molekuljarnye mehanizmy holodoustojchivosti rastenij. Vestnik RAN 75(4), 90-95.

Lubsandorzhieva, P.B., 2009. Soderzhanie biologicheski aktivnyh veshhestv v nekotoryh rastenijah Zabajkal'ja i ih antioksidantnaja aktivnost'. Himija Rastitel'nogo Syr'ja 3, 133-137.

Mironenko, T., 2002. Derevo zhizni. AiF Zdorov'e.

Nicolson, S.W., Human, H., 2013. Chemical composition of the 'low quality' pollen of sunflower (Helianthus annuus L., Asteraceae). Apidologie 44(2), 144-152.

Özler, H., Pehlivan, S., Bayrak, F., 2009. Analysis of free amino acid and total protein content in pollen of some allergenic taxa. Asian J. Plant Sci. 8, 308-312.

Pascoal, A., Rodrigues, S., Teixeira, A., Feás, X., Estevinho, L.M., 2014. Biological activities of commercial bee pollens: Antimicrobial, antimutagenic, antioxidant and antiinflammatory. Food Chem. Toxicol. 63, 233-239.

Pomés, A., 2008. Allergen structures and biologic functions: The cutting edge of allergy research. Curr. Allergy Asthma Rep. 8, 425-432.

Přidal, A., 2003. Včelí produkty - cvičení. Mendelova zemědělská a lesnická univerzita $\mathrm{v}$ Brně, Brno.

Puc, M., 2012. Artificial neural network model of the relationship between Betula pollen and meteorological factors in Szczecin (Poland). Int. J. Biometeorol. 56, 395-401.

Radiologichnyj stan terytorij, vidnesenyh do zon radioaktyvnogo zabrudnennja (u rozrizi rajoniv), 2008. Ministerstvo
Ukrai'ny z pytan' nadzvychajnyh sytuacij ta u spravah zahystu naselennja vid naslidkiv Chornobyl's'koi' katastrofy. TOV «Intelektual'ni Systemy GEO», Kyiv.

Saarinen, K., Jantunen, J., Haahtela, T., 2011. Birch pollen honey for birch pollen allergy - A randomized controlled pilot study. Int. Arch. Allergy Immunol. 155, 160-166.

Saeheng, S., Wongnawa, M., Purintavaragul, C., 2012. Chemical constituents and antioxidant activity of Borussus flabellifer, Elaeis guineensis, Mimosa diplotricha and Mimosa pigra. Medicinal Chemistry \& Drug Discovery 3(1), 52-57.

Schulte, F., Lingott, J., Panne, U., Kneipp, J., 2008. Chemical characterization and classification of pollen. Anal. Chem. 80, 9551-9556.

Sen, S., Chakraborty, R., 2011. The role of antioxidants in human health. Oxidative stress: Diagnostics, prevention and therapy, American Chemical Society, Washington, DC.

Stanley, R.G., Linskens, H.F., 1974. Pollen. Biology, biochemistry, management. Springer-Verlag, Berlin, Heidelberg.

Urbah, V.J., 1963. Matematicheskaja statistika dlja biologov i medikov. Izd. AN SSSR, Moscow.

Vetchinnikova, L.V., Serebrjakova, O.S., Il'inova, M.K., 2012. Zhirnokislotnyj sostav lipidov pyl'cy osnovnyh predstavitelej roda Betula L. Trudy Karel'skogo Nauchnogo Centra RAN 2, 56-62.

Надійшла до редколегї 02.12.2013 